\title{
Strategi Media Online Lensatimur dalam Mengangkat Kearifan Lokal (Studi Kasus Pariwisata Indonesia Timur)
}

\author{
${ }^{1}$ Noviawan Rasyid Ohorella ${ }^{2}$ Kiayati Yusriyah \\ ${ }^{1}$ Fakultas Ilmu Komunikasi Universitas Gunadarma \\ (noviawan_ohorella@yahoo.com) \\ ${ }^{2}$ Fakultas Ilmu Komunikasi Universitas Gunadarma \\ (kiayati@staff.gunadarma.ac.id)
}

\begin{abstract}
Abstrak. Penelitian ini bertujuan untuk mengetahui strategi media online Lensatimur pada website dan konten yang dibuat, mengetahui mekanisme kerja Lensatimur, dan kendala yang terjadi pada produksi. Metode yang digunakan adalah pendekatan kualitatif dimana peneliti mengobservasi dan mewawancarai dengan objek yang diteliti. Hasil Penelitian menunjukkan bahwa operasional Lensatimur berkembang dengan keadaan terbatas terkait pekerja dan manajemen yang ada menghasilkan konten artikel yang kreatif dan inovatif, serta relevan sesuai keunikan masyarakat Timur. Lensatimur menjadi media penyeimbang yang mengangkat kearifan lokal di wilayah Timur, mengalami peningkatan jumlah pembaca per artikel per harinya mencapai 500700 dan pertahunnya mencapai 600 ribu pembaca. Kunci menjadi media favorit antara lain sudut pandang, konten artikel, gaya bahasa, segmentasi khalayak dan inovasi. Mekanisme saat ini ialah pembagian kerja antara editor, penulis, desain grafik dan pengelola website dalam pembuatan konten artikel. Kendala yang dihadapi berfokus pada manajemen waktu dan kurangnya kontributor. Saran yang diberikan adalah Lensatimur harus menambah informasi mendidik bagi para pembaca.
\end{abstract}

\section{Kata Kunci : Strategi, Media Online, Pariwisata.}

Abstract. This study aims to find out Lensatimur's online media strategy on the website and the content created, to find out the mechanism of Lensatimur's work, and the constraints that occur in production. The method used is a qualitative approach where the researcher observes and interviews with the object under study. Research results show that Lensatimur's operations are developing with limited conditions related to existing workers and management producing creative and innovative article content, as well as relevant to the uniqueness of Eastern society. Lensatimur became a counterbalance media that raised local wisdom in the East, experiencing an increase in the number of readers per article per day reaching 500700 and reaching 600 thousand per year. The key to being a favorite media includes 
point of view, article content, language style, audience segmentation and innovation. The current mechanism is the division of labor between editors, writers, graphic design and website managers in making article content. Constraints faced focus on time management and lack of contributors. The advice given is Lensatimur must add educational information to readers.

\section{Keywords: Strategic, Online Media, Tourism.}

\section{Pendahuluan}

Perkembangan jalur akses komunikasi informasi semakin beragam dan tentunya meningkat pesat, tentu hal ini berdampak terhadap pemahaman isi berupa konten yang disampaikan, masyarakat memiliki cara tersendiri dalam menggali informasi yang menjadi tolak ukur perilaku sosialnya. Media cetak semakin hari mengalami ruang yang semakin kecil, tergerus akan media yang berbasis perangkat digital elektronik, walaupun pasar konsumen media cetak tetap ada. Media Massa Online kian menjamur di Indonesia dengan bentuk website dan konten yang berbeda-beda serta menjadikannya sebagai ciri khas ulasan berita yang disampaikan. Semakin banyaknya Media Online yang lahir, tentu memberikan dampak negatif yang cukup signifikan, berkaitan tentang isu yang dibahas yang berbanding terbalik dengan realitas yang sebenarnya. terkait dengan pemberitaan ratna sarumpaet yang diduga telah dianiaya dan kabar berita gempa susulan di Kota Palu yang menimbulkan keresahan warga akan bahaya tsunami yang akan melanda Kota tersebut (https:/ / tekno.kompas.com/read/2018/10/01/10301757/hoaks-informasi-

gempa-81-m-dan-tsunami-susulan-di-palu di akses 26 Oktober Pukul 18.02 WIB).

Media Massa yang berbasis pada portal online terkenal dengan pemberitaan yang sangat cepat dan bersifat headline news, namun banyak yang tidak berfokus pada titik kekuatan kredibilitas informasi yang disampaikan. Bukan hal yang tabu bahkan menjadi lumrah, dikarenakan persaingan yang begitu besar dan berfokus dengan pemberitaan yang tranding topic serta menjadikan banyaknya pembaca sebagai tolak ukur keberhasilan. Fokus inilah yang banyak membuat pembaca senantiasa selalu menjadikan Media bersangkutan sebagai Media favoritnya. Padahal keakuratan dan kredibilitas sumber informasi kian dikesampingkan, hal inilah yang membuat masyarakat menjadi penyimak tanpa bisa berkoar menahan derasnya arus informasi yang belum tentu valid. 
Banyak sekali media Meanstream (media pada umumnya) seperti ini yang bermunculan dalam pasaran, contohnya Media Online Matamata.com, Hitekno.com, dan Bolatimes.com yang memiliki tujuan segmentasi tersendiri yang tak kalah dengan Media Online besar seperti Kompas maupun detik (https:/ / www.viva.co.id/digital/1015713-tiga-media-online-baru-diluncurkanmaret-2018 di akses 26 Oktober Pukul 18.07) karena dilihat jumlah segmentasi pembaca yang terus meningkat dan beragam dalam pengkonsumsian informasi. Tipe pembaca yang mementingkan kecepatan tanpa keakuratan membuat media-media ini semakin tidak terbendung. Media penyelemat memang harus dilahirkan sebagai pengimbang media Meanstream yang ada (media yang berbeda dari biasanya). Salah satunya Media Online Lensatimur dengan tagline Daily Good News From East Indonesia yang mencoba memberitakan kabar positif tentang suatu daerah dalam hal ini daerah Indonesia timur, dengan titik fokus terhadap keakuratan konten tanpa harus mengejar target pemberitaan yang abstrak (tidak mengetahui secara pasti berapa jumlah pembaca da karakteristik pembaca)

Fenomena ini memberikan pernyataan bahwa sangat sulit mencari Media Online yang berfokus pada keakuratan dan kredibilitas sumber informasi tanpa mengikuti kecepatan arus informasi dalam menyampaikan informasi. Media Online Lensatimur merupakan Media Anti Meanstream dari beberapa media sejenis, yang dapat menjadi penyeimbang serta rujukan alternatif masyarakat dalam mendapatkan isi informasi yang kredibel dan akurat. Walaupun memang pertumbuhan media seperti ini masih harus lebih gencar dalam penggunaan strategi yang ada, karena masyarakat terkenal dengan konsep informasi yang cepat namun mengensampingkan kualitas yang ada.

Harus diketahui bahwa perkembangan Media Online meanstream dan Media Online yang berlabel Daily Good News sangatlah berbanding terbalik, sesuai penelitian yang dilakukan oleh (Nugroho, Putri, dan Laksmi, 2012) dalam buku yang berjudul Memetakan Lanskap Industri Media Kontemporer di Indonesia. Dimana hasil penelitian bahwa Indonesia dikuasai oleh 12 raksasa Media Online seperti MNC Group, Mahaka Group, dan Kompas Gramedia (http:/ / cipg.or.id/wp-content/uploads/2015/06/MEDIA-2-Industri-Media-

2012.pdf diakses 26 Oktober 2018 Pukul 18.29). Namun hal ini menjadi peluang besar bagaimana Media Online seperti Lensatimur yang berproses pada kualitas isi informasi dapat bersinergi terhadap peluang pasar yang sangat terbuka dan tentunya akan dijadikan Media pembanding ketika pembaca merasa pemberitaan yang ada pada Media Online Meanstream kurang dapat 
dipahami. Dengan ini dapat ditinjau bahwa peranan strategi dan taktik harus terus ditingkatkan dalam menjawab tantangan yang ada terkait Media Online Lensatimur yang berproses pada penyebaran arus informasi komunikasi.

Lensatimur sebagai Media Online yang berfokus tentang pemberitaan kualitas pertumbuhan dan perkembangan daerah Indonesia timur terkait sumber daya alam (SDA) dan sumber daya manusia (SDM), seperti bidang Pariwisata, Budaya, Adat, Pembangunan Pemerintahan, Musik, Perdamaian, Prestasi Masyarakat dan tentunya Pendidikan, yang semuanya merupakan kabar baik dan dikemas semenarik mungkin dalam pengelolaan website dan konten yang ditampilakan kepada pembaca. Pemberitaan seperti ini jauh dari nuansa politik, hukum, ekonomi dan berita-berita isu nasional lainnya yang kadang memberikan pemahaman konteks yang menyimpang terhadap nalar pembaca. Media Massa juga sebagai alat pembangkit motivasi dalam memperjelas isi konten yang dimaksud (Elfie Mingkid, 2015).

Penelitian ini berfokus pada bagaimana strategi yang dilakukan Media Online Lensatimur dalam memproses ulasan berita pada tampilan website dan konten yang dibuat, kemudian mekanisem kerja di Lensatimur itu sendiri yang dilihat dari perbadingan jumlah staff dan berita yang dibuat dari seluruh pelosok daerah Indonesia timur. Terakhir menganalisa dan mengupas kendala yang sering dihadapi Media Online Lensatimur dalam produksi informasi, tujuan yang dapat dicpai adalah bagaimana sebuah Media penyeimbang yang dalam lingkup besar mampu berproses dalam memberikan informasi yang terdapat banyak kendala, sehingga dari masalah inilah Peneliti mampu memberikan sebuah solusi dan memberikan sebuah pemahaman bahwa pada dasarnya Media Online apapun itu mampu memberikan sebuah edukasi kepada pembaca dalam segmentasi yang sesuai dengan platform yang dipilih Media bersangkutan.

\section{Metode Penelitian}

Pendekatan penelitian yang digunakan adalah metode kualitatif. Menurut (Strauss dan Corbin 2003) dalam (Afrizal, 2014 : 12) metode penelitian kualitatif sebagai jenis penelitian yang temuan-temuannya tidak diperoleh melalui prosedur statistik atau bentuk hitungan lainnya. Dimana metode penelitian kualitatif perlu mencakup cara data yang harus dianalisis secara mendalam dan wawancara yang intens untuk menghasilkan jawaban dari permasalahan yang ada dalam penelitian bersangkutan.

Penelitian kualitatif bertujuan untuk memperoleh gambaran seutuhnya mengenai suatu hal menurut pandangan manusia yang diteliti oleh peneliti. 
Metode kualitatif berhubungan dengan ide dan perspesi informan yang diteliti dan hal-hal tersebut tidak disajikan atau tidak dihasilkan dalam bentuk data angka, dimana terdiri dari berbagai observasi data lapangan dan hasil dari wawancara yang terus dilakukan peneliti kepada para informan yang dibutuhkan.

Peneliti menggunakan paradigma konstruktivisme dalam penelitian bersangkutan, dimana paradigma konstukritivisme mengasumsikan bahwa individu yang ada selalu berusaha memahami dunia dimana mereka hidup dan bekerja (Creswell, 2009). Konstruktivisme juga merupakan komponen utama konsep belajar mandiri, dimana mampu beradaptasi dengan lingkungan terhadap apa yang harus mereka lakukan dalam pembelajaran hidup yang terjadi. Konstruktivisme menyatakan bahwa individu tidak pernah memahami realitas yang sesungguhnya secara ontologis, melainkan tetapi lebih kepada melihat bagaimana kita menjadi tahu akan sesuatu.

Metode yang digunakan peneliti dalam pengumpulan data sebagai berikut:

1. Wawancara Mendalam

Dalam melaksanakan wawancara yang spesifik terhadap informan, peneliti pertama-tama memaparkan pertanyaan yang umum, dimana kemudian didetailkan kepada informan dan dikembangkan ketika melakukan wawancara selanjutnya hingga mendapatkan informasi atau data yang akurat sesuai dengan apa yang diinginkan terkait penelitian bersangkutan. Wawancara yang dilakukan peneliti dalam penelitian kualitatif ialah wawancara dua atau lebih informan seperti bercakapcakap untuk menghasilkan jawaban yang sesuai.

\section{Pengumpulan Dokumentasi}

Peneliti mengumpulkan bahan tertulis berupa hasil wawancara, data dari berbagai sumber informasi yang terdiri atas surat maupun artikel media massa. Semua bukti yang ada dalam dokumentasi nantinya akan menjadi aspek utama dalam menentukan apakah semuanya dalam proses mencari informasi akurat telah detail dan sesuai dengan apa yang diingikan. Sehingga tidak terjadi kesalahan dalam melakukan pencarian informasi.

\section{Melakukan Observasi Terlibat}

Peneliti dituntut untuk dapat mengetahui secara langsung apa yang terjadi dan apa yang perlu diketahui secara terperinci, dengan cara mendengarkan dan terlibat langsung dalam apa yang diteliti. Semua ini 
dilakukan dengan menggunakan teknik observasi terlibat, caranya adalah peneliti bersangkutan harus dapat merasakan kegiatan atau operasional yang terjadi dalam penelitian bersangkutan, mulai dari kegiatan rutinitas hingga penyelesaian jika terjadi permasalahan didalamnya. Dalam penelitian ini ada juga observasi setengah terlibat, dimana peneliti dalam hal ini melakukan observasi dalam kurun waktu tertentu dengan keluar masuk, tanpa harus terus menerus masuk dalam penelitian bersangkutan.

4. Melakukan Diskusi Kelompok Fokus (Focus Group Discussion, FGD)

Salah satu teknik yang bisa dipakai peneliti selain wawancara adalah diskusi kelompok yang lebih fokus dari teknik wawancara. Dimana peneliti akan mengadakan diskusi dengan beberapa orang pilihan yang terkait dengan objek penelitian yang sedang diteliti. Hal ini dilakukan sebagai penopang dari wawancara mendalam yang telah dilakukan terlebih dahulu, sehingga setelah melakukan diskusi kelompok dengan beberapa orang, akan mendapatkan data atau informasi yang detail dan terstruktur sesuai dengan apa yang diinginkan peneliti terhadap penelitian bersangkutan.

Subyek penelitian yang dimaksud ialah subyek yang telah dipersiapkan oleh peneliti untuk diteliti secara mendalam dan terstruktur. Sedangkan obyek penelitian adalah bagian dari bahan yang diteliti serta dijadikan patokan utama maupun titik perhatian dalam penelitian yang akan dibuat. Dalam penelitian yang dibuat ini, subyek yang diteliti adalah staff kerja dalam Media Online Lensatimur yaitu Chief Executive Officer. Adapun dua informan lainnya yaitu pembaca Media Online Lensatimur yang dilihat dari segmentasi tempat tinggal dan umur.

Obyek penelitian yaitu pengelolaan Media Online Lensatimur terkait perkembangan dan manajemen komunikasi oleh para staff dengan tugasnya masing-masing yang memiliki keterkaitan satu dengan yang lain dalam beroperasinya media bersangkutan.

Peneliti menggunakan teknik analisis data dari Miles dan Huberman. Peneliti menulis kembali catatan yang didapat selama melakukan observasi di lapangan sesuai dengan yang diinginkan dalam penelitian bersangkutan. Seperti halnya wawancara yang harus direkam dan kemudian dilanjutkan dengan melakukan transkrip hasil wawancara tersebut dalam lembaran, begitupun dengan catatan-catatan yang selama observasi ditulis dan harus dipelajari lebih detail. Maka dari itu peneliti dapat menentukan mana informasi 
yang paling penting dan informasi yang biasa saja. Peneliti harus mampu mengidentifikasi dengan cermat untuk menghasilkan penelitian yang baik dan tentunya berkualitas.

Triangulasi yang dilakukan peneliti adalah dengan menggunakan triangulasi metode yaitu dengan cara peneliti membandingkan informasi atau data dengan cara yang berbeda. Dalam penelitian kualitatif peneliti menggunakan metode observasi dan wawancara untuk memperoleh kebenaran informasi yang handal dan gambaran yang utuh mengenai informasi yang diteliti. Hal ini dilakukan untuk mengecek kebenaran informasi tersebut, apakah observasi yang dilakukan peneliti sama dengan apa yang disampaikan informan saat di wawancarai. Dimana informan dalam penelitian ini terbagi atas tiga informan, dimana setiap jawaban dari hasil wawancara tentunya berbeda dan harus dilihat saling keterkaitan dari jawaban yang ada.

\section{Hasil dan Pembahasan}

Teori New media atau media baru merupakan istilah yang digunakan untuk semua media komunikasi yang berlatar belakang teknologi komunikasi dan informasi. Istilah media baru telah digunakan sejak tahun 1960-an dan telah mencakup seperangkat teknologi komunikasi terpaan yang semakin berkembang dan beragam (McQuail, 2011). Perkembangan arus komunikasi informasi akhir-akhir ini semakin membuat perkembangan teknologi yang lebih muktahir, banyak perangkat teknologi yang bukan hanya menampilkan sisi kreatifitas namun memberikan efisiensi dalam melakukan kegiatan yang berhubungan dengan visualisasi konten digital, bahkan dapat membuat komunitas-komunitas dunia maya yang kadang tidak terlihat jelas, namun banyak yang tahu dengan keberadaan komunitas bersangkutan.

New media memberikan akses yang lebih, agar bagaimana masyarakat atau khalayak dapat terintegrasi dengan mudah dalam pengkonsumsian komunikasi informasi, salah satunya Media khusunya Media Online dalam hal ini Media Online Lensatimur. Bagaimana memberikan sentuhan artistik terhadap website dan berbagai hal yang ditampilkan dalam tampilan website berupa fitur dan konten yang menarik. Karena masyarakat atau khalayak sekarang ini lebih berpegang kepada bagaimana mencari sesuatu yang dapat mudah diakses, namun memberikan edukasi dan informasi yang sangat banyak.

Selanjutnya Teori Difusi Inovasi Artikel berjudul The People's Choice yang ditulis oleh Paul Lazarfeld, Bernard Barelson, dan H. Gaudet pada tahun 1944 menjadi titik awal munculnya teori difusi inovasi. Di dalam teori ini dikatakan 
bahwa komunikator yang mendapatkan pesan dari media massa sangat kuat untuk memengaruhi orang lain. Dengan demikian, adanya inovasi (penemuan), lalu disebarkan (difusi) melalui media massa akan kuat memengaruhi massa untuk mengikutinya. Berbicara tentng inovasi, media massa khusunya Media Online dalam hal ini Media Online Lensatimur dituntut untuk melakukan pembaharuan yang mampu meningkatkan perkembangan media bersangkutan. Inovator dimana merupakan pimpinan atau pekerja dalam Media Online harus sebisa mungkin membaca perkembangan masyarakat atau khalayak sebagai target, apa yang dibutuhkan dan bagaimana perkembangan tingkah laku terhadap pemenuhan kebutuhan di lingkungan sosial. Inilah yang terjadi pada Media Online Lensatimur. Sebisa mungkin membaca karakter pembaca dan tentunya harus menghasilkan tampilan website yang menarik dan konten berita yang terus mengedukasi dan menginformasi secara persuasif.

Kondisi psikologis sangat berpengaruh dalam teori difusi inovasi, karena masyarakat dalm artian pembaca sangatlah suka dengan hal-hal baru yang tentunya memberikan hasil positif juga kepada mereka. Inilah peluang besar yang harus dimanfaatkan oleh Media Online untuk menjadikan medianya sebagai rujukan referensi masyarakat untk pemenuhan kebutuhan informasi. Karakteristik masyarakat Daerah Indonesia Timur yang mengalami peningkatan berinternet, harus dapat dimudahkan dengan munculnya Media Online yang mengedukasi seperti Media Online Lensatimur. Masyarakat akan menjadikan Media Online Lensatimur sebagai rujukan utama, begitupun Medianya harus mampu berinovasi mengikuti keinginan pembaca agar tetap beroperasi sebagai Media Good News kepada masyarakat Daerah Indonesia Timur itu sendiri.

Teori Manajemen Komunikasi berbicara mengenai apa yang akan dilakukan untuk mencapai tujuan dari berbagai sudut pandang dan keefektifan dalam mengolah sumber daya yang ada. Kata manajemen berarti pemimpin, direksi, dan pengurus yang diambil dari kata kerja "manage". Kata ini mengandung arti mengemudikan, mengurus, dan memerintah. Menurut bahasa Italia, istilah manajemen berasal dari "managiere" yang berarti melatih kuda sebagai pelatih, dan istilah manage dalam bahasa Perancis bermakna tindakan membimbing atau memimpin. Dalam teori ini juga dapat ditarik pengertian bahwa sebuah media massa khususnya Media Online memiliki cara kerja tersendiri yag mengantarkannya pada tujuan jangka pendek maupun jangka panjang, karena hal ini dirujuk pada bagaimana mengolah rumah tangga media bersangkutan agar tidak terjadi perpecahan dalam 
perkembangannya dan mampu berjalan sesuai dengan misi yang diemban media bersangkutan.

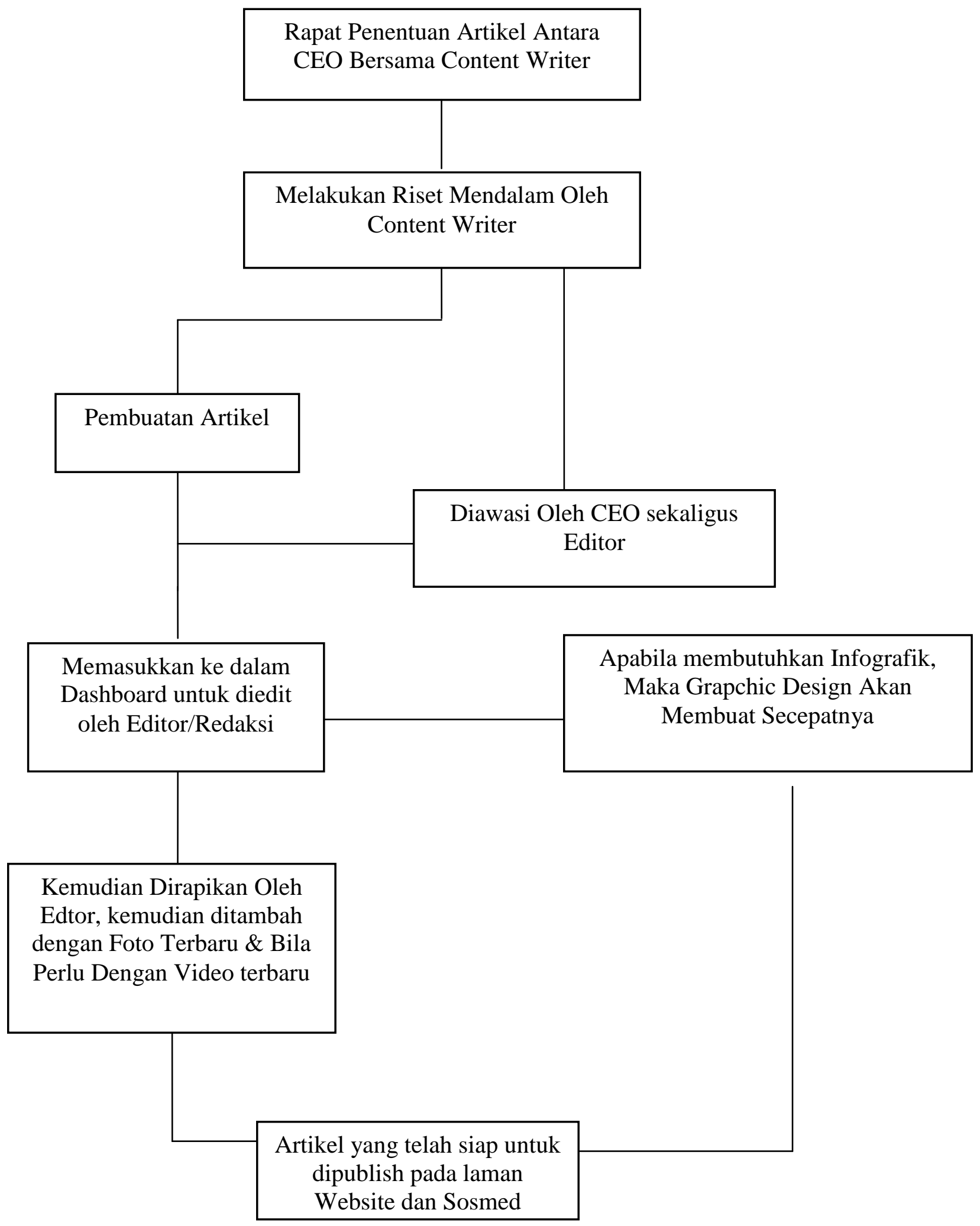

Gambar 1. Mekanisme Kerja Pembuatan Artikel 
Media Online Lensatimur memiliki manajemen tersendiri, mulai manajemen pembagian tugas yang meliputi tata cara kerja dan mekanismenya seperti apa, hingga manajemen waktu dalam mempublish konten hingga melakukan interaksi dengan pembaca dan antar staff pekerja di dalam Media Online Lensatimur. Setiap media memiliki manajemen yang berbeda, namun persamaannya ialah manajemen waktu, karena Media Online berorientasi dengan perkembangan waktu dan nilai jual berita yang disebar. "management is performance of conceiving desired results by means of group efforts consisting of utilizing human talent and resources" (Teryy, dalam Syafaruddin, 2005).
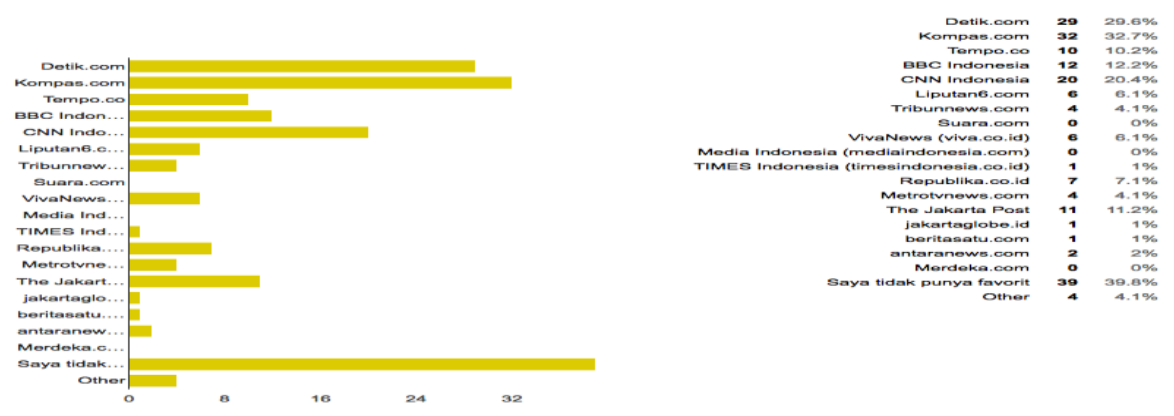

Gambar 2 Daftar Media Online

(Sumber : https:/ / medium.com/@bobbypriambodo/hasil-survei-kepercayaanterhadap-berita-online-d09afb702219)

Banyak Media Online yang kian menjamur di Indonesia, mulai dari sudut pandang yang mengarah kepada isu nasional seperti politik, ekonomi, hukum dan sosial dan Media dengan sudut pandang Lifestyle yang lebih menitikberatkan kepada isu terkait kecantikan, gaya dan perjalanan. Mediamedia yang dimaksud tidak terfokus memberitakan apa yang bisa dikatakan sebagai penyegaran terhadap komunikasi informasi. Banyak Media yang hanya memberitakan sesuatu yang Viral \& mencari berita yang sama dengan Media lainnya, sehingga tidak ada pembanding antara Media yang satu dengan Media lainnya. Inilah yang menjadi keprihatinan, salah satunya yang menjadi imbas adalah Daerah Indonesia Timur, dimana potensi yang luar biasa untuk diekspos, namun memiliki wadah yang sedikit untuk diberitakan pada Media khususnya Media Online.

Wilayah Indonesia Timur begitu luas, dari mulai daratannya hingga lautannya. Semua itu memiliki potensi yang luar biasa. Mulai dari Nusa Tenggara, Sulawesi, Kepulauan Maluku dan Papua. Sehingga terpikirkan bahwa mengapa tidak diciptakannya suatu Media Online yang titik fokusnya kepada wilayah timur namun segmentasinya bukan hanya masyarakat timur 
melainkan masyarakat Indonesia dan internasional karena mudah diakses. 15 Mei 2017 Lensatimur resmi dilaunching kepada publik bertepatan dengan nuansa perayaan Hari Pattimura dengan artikel perdana yaitu sepak terjang sejarah Kapitan Pattimura. Lensatimur sendiri memiliki tagline Daily Good News From Indonesia dengan logonya yang berlatar warna biru dengan tulisan LT berwarna putih.

Tagline yang dipakai ialah Good News menjadikan Lensatimur berbeda dengan Media Online lainnya karena berfokus pada kabar baik terkait dengan pengembangan wilayah Indonesia Timur mulai dari kearifan lokal, pariwisata, sejarah, budaya, adat istiadat, prestasi anak timur dan pembangunan daerah. Begitupun dengan logo yang dipakai yang sangat mencermikan Indonesia Timur dimana wilayah lebih banyak lautan, maka background yang dipakai adalah warna biru sebagai cerminan dan tulisan LT yang berwarna putih mewakili pulau yang ada di wilayah timur Indonesia.

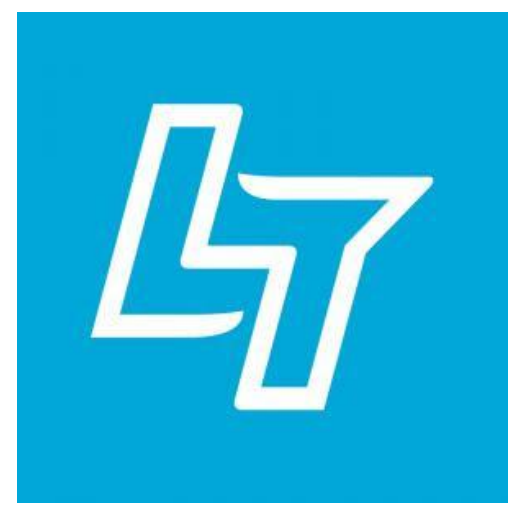

Gambar 3. Logo

(Sumber: Media Online Lensatimur)

Misi yang dibuat oleh Lensatimur ialah Kami percaya bahwa dengan berimbangnya informasi, akan lahir peluang yang lebih adil bagi tumbuhnya harapan dan gagasan dari generasi baru Indonesia Timur untuk menjadi yang terbaik. Hal ini diperjelas dalam Wawancara CEO Lensatimur "Desain yang simple dan penempatan iklan yang rapi membuat website Lensatimur tetap friendly di mata pembaca" (Wawancara Salman Faris Alkatiri, CEO, 8 Juni 2018). Media Online Lensatimur dapat dikatakan sebagai sosio-digital startup yang digagas oleh Komunitas Sagu Maluku dan merupakan pemilik dari Saudara Salman Faris Alkatiri. Platform Media ini menyediakan informasi menarik yang menginspirasi pembaca dari Daerah Indonesia Timur yang mencakup Sulawesi, Nusa Tenggara, Kepulauan Maluku dan Papua. Konten 
berita informasi yang ditampilkan dan disajikan di website kepada pembaca berkisar tentang Pariwisata, Kuliner, Budaya, Destinasi Favorit, Inspirator Pemuda Timur, Karya Indonesia Timur, Pagelaran Acara Timur. Yang dikemas secara kreatif dalam mahakarya Media Online Lensatimur. Dikatakan kreatif karena Media ini tidak hanya menghadirkan artikel konten berita melainkan dalam bentuk gambar, info grafik, motion grafik hingga video yang sangat menarik. Tujuan utama dari Media Online Lensatimur ialah memperkenalkan Daerah Indonesia Timur dari sisi keindahan, kekayaan alam dan budaya, potensi ekonomi kreatif, serta kreatifitas dan prestasi yang dilahirkan oleh para Pemuda Pemudi Indonesia Timur.

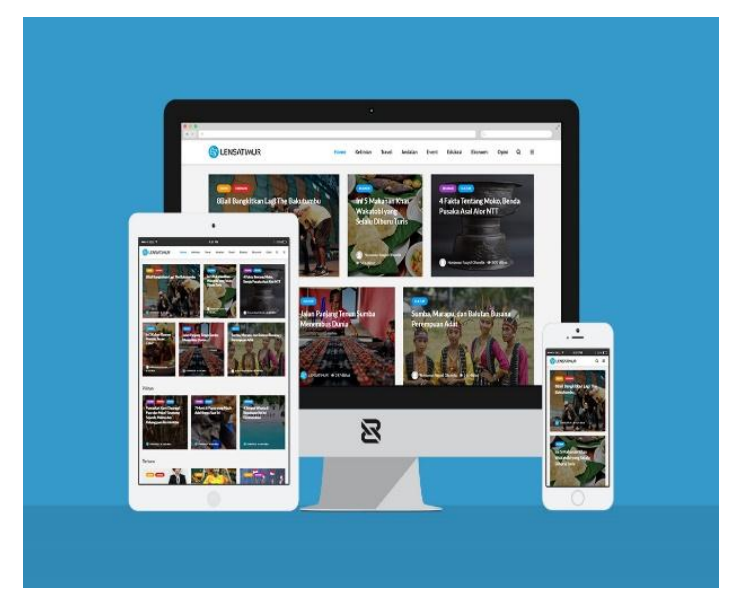

Gambar 4. Tampilan Website

(Sumber: Media Online Lensatimur)

Hal ini diperjelas oleh CEO Lensatimur dalam kutipan wawancara "Konten yang bisa bersentuhan langsung dengan apa yang dicari anak muda yaitu fun dan tidak kaku" (Wawancara Salman Faris Alkatiri, CEO, 8 Juni 2018). Perkembangan Media Online Lensatimur kian tumbuh pesat, dimana pertama kali di launching tidak ada ekspetasi yang berlebihan terhadap pesatnya pertumbuhan Lensatimur. Namun semakin hari banyak pembaca yang tertarik dengan Media Online ini dan menjadi perbincangan masyarakat timur, dapat dikatakan Lensatimur sebagai barometer Media Online yang titik fokusnya hanya pada wilayah timur Indonesia dan ini menjadi suatu penyegaran dan cita-cita masyarakat timur yang baru dapat terealisasikan pada tanggal 15 Mei 2017. Artikel yang Lensatimur buatpun semakin beragam dari berbagai daerah di timur Indonesia dan konten yang diangkat, tentunya yang jarang diekspos oleh Media Meanstream bahkan anak timur pun baru tahu tentang sejarah dan objek pariwisata lainnya di Media Online Lensatimur. 
Bahkan beberapa kali artikel maupun videografik yang dibuat menjadi viral di Media Sosial bahkan dishare dari laman website yang sangat banyak.

Sebagai Media Online yang baru berkiprah dan mengambil titik fokus terhadap pengembangan potensi wilayah Indonesia Timur sudah pasti memiliki kekuatan dan kelemahan tersendiri, apalagi segmentasi khalayaknya adalah masyarakat timur sendiri dan sisanya adalah masyarakat Indonesia dan internasional. Berbeda dengan Media Online besar yang jika ditelusuri sudah berkiprah cukup lama dan strategi yang dijalankan juga telah mengalami kamuflase secara berkelanjutan yang dapat dilihat dengan terus adanya pembaharuan baik secara bertahap maupun secara keseluruhan.

Yang harus dititikberatkan pada Strategi dan Taktik adalah beberapa poin yang menjadi acuan standar dalam pengembangan suatu Media Online, diantaranya dari sudut pandang, dimana bahwasanya Media Online Lensatimur lebih mengarah kepada sebuah informasi yang komunikatif dan bersahabat terkait dengan apa yang sering dialami dan menjadi ciri khas masyarakat timur pada umumnya. Konten Artikel yang berfokus seperti pariwisata, budaya, adat, sosial dan lainnya. Gaya Bahasa yang digunakan juga lebih kepada bahasa Indonesia yang dapat dimengerti oleh semua pembaca, tidak baku namun dapat dipahami dengan baik. Segmentasi Khalayak yang dimaksud adalah target pembaca adalah masyarakat Indonesia timur itu sendiri walaupun pada perjalananya ada masyarakat dari daerah lain atau bahkan internasional yang mengakses website Lensatimur. Inovasi yang terus dilakukan terkait tampilan website, penyajian informasi hingga penunjang seperti poster, video, dan lainnya. Ini pula diperjelas oleh CEO Lensatimur dalam kutipan wawancara "Strateginya adalah dengan mengangkat konten yang relevan dengan anak muda. Agar menarik audiens, judul dan cover artikel dibuat semenarik mungkin agar ada call to action kepada calon pembaca untuk membaca artikel tersebut. Karena memang Lensatimur dihadirkan untuk mensinergikan para pemuda Indonesia timur yang semakin kreatif dan inovatif" (Wawancara Salman Faris Alkatiri, CEO, 8 Juni 2018).

Hal ini juga berkaitan dengan Analisis Swot sebagai bagian dari metode perencanaan strategis sebuah media online yang bertujuan untuk mengevaluasi kekuatan (strenghths), kelemahan (weaknesses), peluang (opportunities), dan ancaman (threats). Berbicara mengenai media online Lensatimur tentunya memiliki kekuatan maupun kelemahan dalam segi operasional, baik itu terlihat maupun tidak terlihat. Ini semua dikarenakan ada beberapa hal teknis yang tidak dimiliki oleh Lensatimur seperti Media Online pada umumnya. 
Peluang yang ada dan harus secepatnya diambil oleh Lensatimur adalah segala macam pemberitaan yang berlabel Good News di Indonesia timur, dikarenakan banyak sekali hal yang belum pernah dipublish dan terdiri dari berbagai aspek dan peluang berikutnya adalah segmentasi jumlah pembaca yang harus terus digarap, apalagi jumlah penduduk di Indonesia timur lumayan besar. Untuk ancaman, media online Lensatimur harus terus berinovasi dari mulai tampilan website, konten artikel ataupun hal teknis lainnya, karena kedepannya bisa jadi banyak bermunculan media online yang sama persis dengan Lensatimur dilihat dari perspektif dan konten yang diangkat. Maka dari itu ada pembaharuan yang secara berkesinambungan dari pihak Lensatimur.

Berikut penjelasan CEO dalam wawancara "Lensatimur dikerjakan secara kolektif oleh 3 orang. Orang pertama yang mengurus hal teknis website, orang kedua menulis editor dan grafis, orang ketiga sebagai kontributor yang mensubmisi artikel untuk ditayangkan. Jadi yang mengurus hal teknis website disebut Chief Technology Officer dia mengurus mulai dari perkembangan website, hosting, layanan google ads dan sebagainya. Yang menulis editor dan grafis adalah CEO maupun Grapchic Design, dimana editor dalam hal ini menerima artikel dari contributor yang dimasukkan dalam dashboard baru kemudian dilakukan penyaringan dan apabila artikelnya cocok dibuatkan grafis, maka grafis bersangkutan akan ditampilkan dalam artikel maupun sosial media. Terakhir Kontributor yang akan menulis dan mencari berita untuk dijadikan artikel, namun sebelum melakukan hal ini, kontributor telah melakukan rapat bersama CEO terkait konten berita" (Wawancara Salman Faris Alkatiri, CEO, 8 Juni 2018). Yang dilakukan adalah sebagai berikut :

1. Mencari artikel yang benar-benar dibutuhkan oleh masyarakat.

2. Membuat isi artikel secara jelas dan runut.

3. Berkomunikasi atau berinteraksi melalui sosial media snapgram.

4. Menciptakan konten ringan untuk dipublish di sosial media.

5. Membuat Infografik ringan dan menarik.

6. Menciptakan Videografik yang keren dan menakjubkan. 
Terkait artikel yang dibutuhkan oleh masyarakat, akan ada namanya penyaringan yang dilakukan oleh CEO bekerjasama dengan Content Writer. Ada beberapa aspek berita yang dibutuhkan oleh masyarakat dan didapat dari:

1. Pembahasan yang sedang hangat di masyarakat.

2. Yang sedang viral di Media Massa lainnya.

3. Mencari tahu dan meneliti apa yang jarang diketahui oleh Masyarakat.

Biasanya informasi-informasi akan disatukan dan akan di diskusikan bersama untuk menetapkan mana saja yang pantas dijadikan artikel dan dikonsumsi oleh pembaca Lensatimur. Ini terkait dengan staff dan juga riset yang dilaksanakan. Karena kendala yang dialami bahwa tidak adanya kontirbutor yang dapat membantu mencari informasi yang dapat dijadikan artikel, yang dijelaskan CEO dalam wawancara "Karena Lensatimur dimotori oleh SDM yang sangat minim secara jumlah dan tiap-tiap orang memiliki kesibukan masing-masing, maka artikel di Lensatimur lebih sering diposting saat editor sekaligus admin website memiliki waktu luang. Memang banyak bahan berita yang dapat dijadikan artikel, namun semua terkendala akan penulis dan editor. Padahal banyak kunjungan atau pembaca terus meningkat, hal inilah yang menjadi kendala utama kami. Maka dari itu Kami mencari artikel yang benar-benar mampu menarik perhatian khalayak \& membuat artikel sedetail mungkin" (Wawancara Salman Faris Alkatiri, CEO, 8 Juni 2018).

Terkait dengan riset, maka tergantung topik dan pilihan yang akan dibahas, wilayah Indonesia Timur memang kerap didentikkan dengan adat dan warisan leluhur yang masih jarang untuk diekspos bahkan sulit untuk mencari informasi terkait dengan keberadaan dan rutinitas ritual yang mereka lakukan. Sehingga jika memang Lensatimur ingin mengangkat topik tentang hal itu, konsekuensi yang dihadapi adalah sebisa mungkin melakukan riset yang mendetail sampai dimana titik penyelesaian dapat diselesaikan dan siap diolah menjadi artikel khas Lensatimur. Karena dalam Media Online Lensatimur, aka nada namanya campuran antara artikel ringan dan berat namun tetap disuguhkan dengan bahasa yang ringan dan mudah dimengerti. Hal ini diperjelas oleh CEO Lensatimur dalam wawancara "Tergantung kedalaman artikel. Ada yang sampai satu minggu, ada juga yang hanya hitungan jam. Riset yang lama berkaitan dengan sejarah contohnya sejarah perjanjian breda antara banda dan manhattan, suku kanibal di papua dan sejarah perjuangan pahlawan pattimura dengan segala perjanjian dengan penjajah serta ritual adat karnaval abda'u. Yang dimana jika ada kesalahan dalam artikel akan beresiko tinggi. Sehingga riset harus benar-benar sesuai dengan relaitas yang ada. 
Referensi yang dipakai biasanya dari Buku, cerita dari penduduk asli sana dan beberapa dari sumber online terpercaya" (Wawancara Salman Faris Alkatiri, CEO, 8 Juni 2018).

Sudut Pandang hingga Inovasi yang menjadi cerminan paling utama atau dasar pijakan, apakah Media Online yang dimaksud bisa bertahan lama atau tidak. Apalagi sekarang bermunculan berbagai Media Online pesaing yang kadang hanya menjadi peramai dengan berita yang tidak akurat atau menjadi penyaing dengan gagasan inovasi yang unik dan berbeda. Masyarakat pada umumnya mencari kesegaran dalam pemenuhan kebutuhan informasi, maka jelas kaitannya dengan sumber dan wadah mengakses informasi yang dibutuhkan secara detail dan terperinci. Inilah yang harus yang harus bisa dikelola dengan baik oleh Media Online Lensatimur sebagai Media yang baru. Memang jika dilihat pangsa pasar atau segmentasi khalayaknya sangat luas dan berpotensi besar apabila digarap secara serius, namun kelemahan yang terjadi adalah bagaimana Media yang baru dan kecil seperti Lensatimur harus bisa menampilkan yang menjadi ciri khas, agar khlayak tidak berubah arah untuk lebih mengakses Media Online besar secara Nasional.

Tabel 1

Daftar Artikel Media Online Lensatimur

(Sumber Media Online Lensatimur)

\begin{tabular}{|c|l|}
\hline Nomor & \multicolumn{1}{|c|}{ Judul } \\
\hline 1. & Ini 5 Makanan Khas Wakatobi Yang Selalu Diburu Turis \\
\hline 2. & 4 Fakta Tentang Moko, Benda Pusaka Asal Alor NTT \\
\hline 3. & Ini 3 Kuliner Ekstrim Manado, Berani Coba ? \\
\hline 4. & Jalan Panjang Tenun Sumba Menembus Dunia \\
\hline 5. & Sumba, Marapu, dan Balutan Busana Perempuan Adat \\
\hline 6. & Pantaskah Kami Dipanggil Pace dan Mace \\
\hline 7. & 7 Mumi Papua Yang Masih Ada Hingga Saat Ini \\
\hline 8. & 4 Wisata di Kepulauan Kei Yang Wajib Dikunjungi \\
\hline 9. & Persepsi Abal Abal Tentang Orang Indonesia Timur \\
\hline 10. & Alasan Dibalik Kanibalisme Suku Korowai di Papua \\
\hline 11. & $\begin{array}{l}\text { Ini } 5 \text { Cara Kreatif Orang Maluku Dalam Memelihara } \\
\text { Perdamaian }\end{array}$ \\
\hline
\end{tabular}




\begin{tabular}{|c|l|}
\hline 12. & 8 Kuliner Makassar yang Bikin Goyang Lidah \\
\hline 13. & Pulau Pombo, Cagar Alam Maluku Yang Tak Berpenghuni \\
\hline 14. & $\begin{array}{l}\text { 5 Fakta Tentang Perahu Belan dan Nilai Demokrasi di } \\
\text { dalamnya }\end{array}$ \\
\hline 15. & $\begin{array}{l}\text { 4 Hal Yang Harus Kamu Ketahui Jika Ingin Menikahi } \\
\text { Wanita Bugis }\end{array}$ \\
\hline 16. & Inilah 7 Momen Sakral Dalam Karnaval Abda'u di Maluku \\
\hline
\end{tabular}

Aspek yang menjadi keunggulan Media Online Lensatimur terkait dengan artikel Pariwisata yang menjadi keunggulan dari daerah Indonesia timur. Buktinya adalah Pariwisata Bahari mulai dari Pantai yang masih alami, Pulau-pulau kecil yang saling berdekatan, terumbu karang yang sehat, warna warni dan beraneka jenis dan keindahan alam bawah laut yang menjadikan wilayah Indonesia Timur sebagai surganya penyelam dan rumah bagi $80 \%$ spesies terumbu karang dan sebagian populasi jenis ikan diseluruh dunia. Spot atau objek wisata yang memang memiliki nama hingga mancanegara yaitu Komodo, Wakatobi, Bunaken, Banda, Morotai, dan Raja Ampat. Namun selain itu ada artikel top terkait pariwisata bahari yang dimuat oleh Lensatimur ialah Wisata di Kepulauan Kei yang memiliki pasir putih panjang $3 \mathrm{Km}$ dan menduduki nomor 2 sebagai pasir terhalus di dunia serta Pulau Pombo yang menjadi cagar alam tak berpenghuni dengan beranekaragam jenis terumbu karang dan spesies burung langka yang dinamakan burung Pombo. "Banyak hal unik yang diberikan dalam Media Online Lensatimur mulai dari website dan sosial media yang dipakai. Salah satunya yang saya rasa adanya keunikan adalah artikel tentang Moko benda yang menjadi bagian sejarah panjang masyarakat alor. Karena keunikan yang ada memberikan pemahaman yang luas bagi kita para pembaca" (Wawancara Akmal Tawainella, Pembaca \& Informan 2, 4 Juli 2018). 


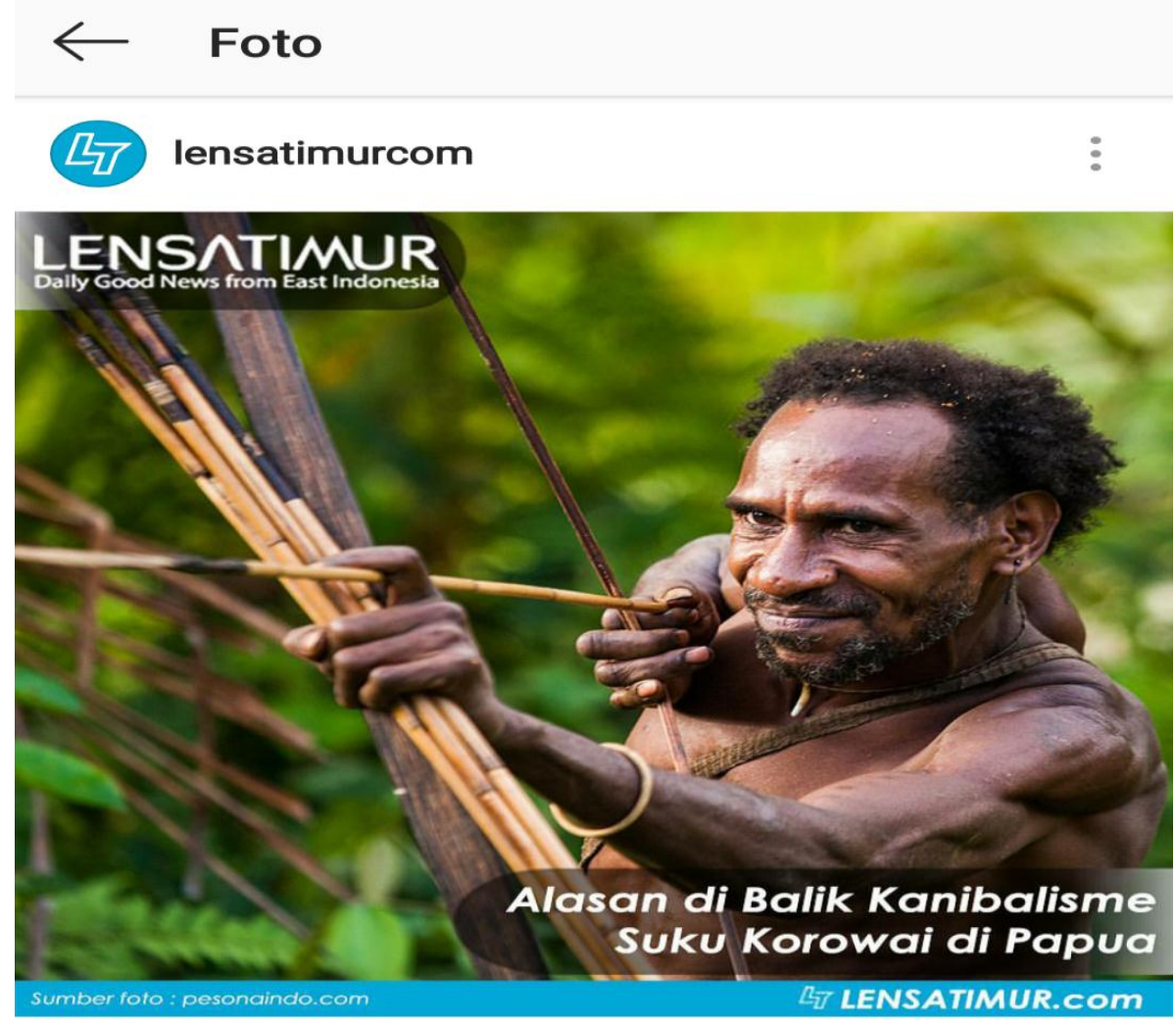

Gambar 5. Contoh Artikel

(Sumber Media Online Lensatimur)

Aspek selanjutnya ialah Sosial Budaya sebagai bagian dari interpretasi perilaku masyarakat dalam lingkungan sekitar yang dilakukannya terhadap masyarakat lain maupun kepada alam, artikel top Lensatimur terkait hal ini, antara lain Tenun Sumba Menembus Dunia, Busana Perempuan Adat, Panggilan Pace dan Mace, Persepsi Abal Tentang Orang Timur, cara Kreatif Orang Maluku Memelihara Perdamaian. Semua ini adalah bentuk ungkapan dengan apa yang terjadi di wilayah timur dan tentunya semakin membuka mata masyarakat manapun, bahwa ternyata masyarakat Indonesia timur telah mengalami perkembangan pesat jauh sebelum sekarang ini dengan kehidupan sosial masyarakatnya yang bersuku-suku dan hidup berpindah-pindah. "Berharap sekali sama Lensatimur agar lebih giat memberitakan tentang potensi Indonesia timur" (Wawancara Rizkiyah Tuasalamony, Pembaca \& Informan 3, 5 Juli 2018).

Pada prinsipnya sebisa mungkin Media Online Lensatimur menjadi wadah bagi potensi yang ada di Indonesia Timur sesuai dengn tagline yang dimiliki yaitu Good News From East Indonesia. Maka dari puluhan hingga ratusan artikel yang ada di laman website Lensatimur, sekiranya gambaran besar yang dapat saya ambil dari sekian banyak terkait kearifan lokal ialah 
Makanan, Sejarah, Pariwisata, dan Sosial Budaya. Walaupun aspek yang lain masih ada, namun keempat aspek ini adalah gambaran bahwasanya Lensatimur terfokus dan lebih mengembangkan hal-hal seperti ini. Sesuai dengan hasil wawancara "Agar Indonesia timur memiliki citra baik di mata publik. Ini adalah cita-cita mendasar bagaimana Lensatimur berkiprah dari sudut pandang yang sangat rasional. Kemudian lebih menghasilkan kontenkonten yang lebih baik dan tentunya lebih meningkatkan jumlah pembaca dari tahun sebelumnya. Ini merupakan prioritas kami, bila perlu kami juga menyasar pembaca internasional dengan mempublish artikel dengan bahasa inggris" (Wawancara Salman Faris Alkatiri, CEO, 8 Juni 2018).

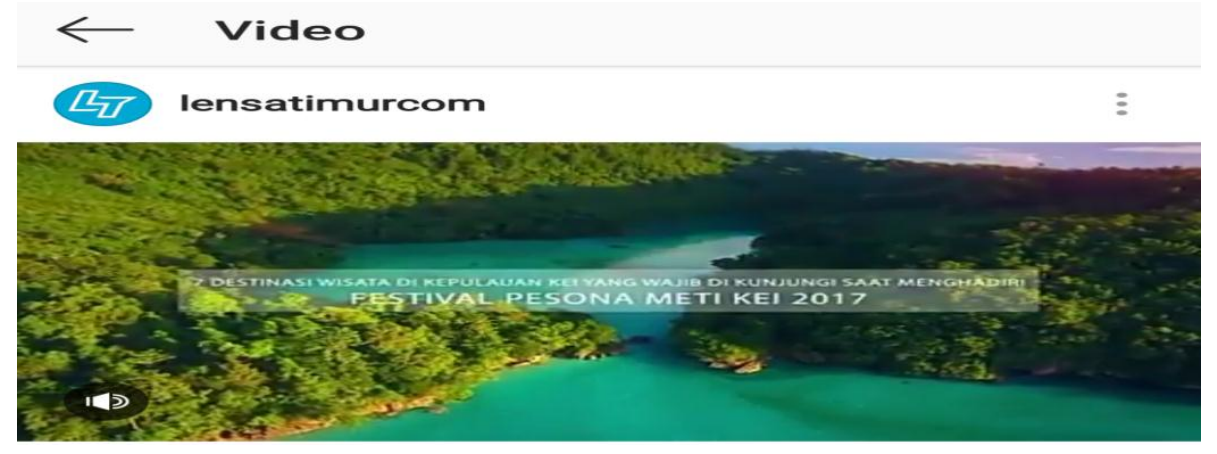

Gambar 6. Contoh Artikel

(Sumber Media Online Lensatimur)

Apapun yang dibuat akan menerima imbalan yang berkali-kali lipat melebihi apa yang telah dilakukan, mungkin ini sangat cocok diberikan kepada Media Online Lensatimur. Pada hakekatnya Lensatimur mencoba menjadi media penyeimbang terhadap Media meanstream yang terlalu fokus terhadap berita pasaran yang memang pada akhirnya membuat semua media memiliki informasi yang sama dari segala aspek, mulai judul, pengantar, isi dan foto yang dipublish pun sama. Merasa bahwa ada yang kurang dari Indonesia timur, membuat Lensatimur coba untuk memaksimalkan kekosongan itu dengan sudut pandang pemberitaan yang fokus terhadap mengangkat segala potensi yang ada.

Banyak Daerah dan banyak Kearifan lokal yang terangkat namanya hingga ke nasional maupun mancanegara dengan publikasi yang dilakukan Oleh Lensatimur. Ini merupakan sebuah komitmen yang saling bersinergi bagaimana cara agar Indonesia timur dikenal luas, bukan sebagai wilayah terpinggirkan dan menjadi wilayah yang kaya akan berbagai macam keindahan yang ada didalamnya. Itulah yang menjadikan Media Online Lensatimur diajak untuk menjadi Media Partner tunggal dalam Karnaval Abda'u di Desa Tulehu Maluku yang termasuk dalam Kalender Pariwisata Nasional, begitupun 
dengan kerjasama yang dilakukan oleh Designer Indonesia Didiet Maulana yang menggandeng Lensatimur sebagai perwakilan tunggal dalam Media Publikasi Lokal terkait project Bhumi Sumba Nusa Tenggara Barat, selain itu Lensatimur menjadi Media publikasi utama dalam Pesona Festival Meti Kei di Maluku Tenggara yang dihadiri langsung oleh Menteri Pariwisata, kemudian kerjasama bersama Official Account Pendaki Indonesia yang melakukan survei terkait Gunung Favorit untuk mendaki yang tersebar di wilayah Indonesia timur. Dan yang terakhir Lensatimur menjadi Media penyalur pendidikan terkait kerjasama Manise Project di Maluku yang dihadiri oleh Miss Indonesia.

Berikut hasil wawancara terkait "Ada tentunya, salah satu yang mengesankan dalam kerjasama ini adalah project Bhumi Sumba milik designer papan atas Indonesia yaitu mas didiet maulana yang mengajak kami untuk menjadi media partner mereka dalam program-program yang mereka kerjakan terkait dengan ikat tenun sumba yang di desain untuk menjadi sebuah pakaian yang modis" (Wawancara Salman Faris Alkatiri, CEO, 8 Juni 2018). Dan dipertegas dalam wawancara berikutnya "Saya mengenal media online lensatimur semenjak media ini menjadi media partner tunggal di salah satu event besar pariwisata Maluku yaitu Karval Abda'u Tulehu dan kebetulan saya juga menjadi bagian dari event tersebut. Mulai dari situ saya mengetahui Lensatimur dan membaca serta mengikuti tiap artikel yang dipublish, karena menurut saya menarik dan beda dengan media lainnya" (Wawancara Rizkiyah Tuasalamony, Pembaca \& Informan 3, 5 Juli 2018).

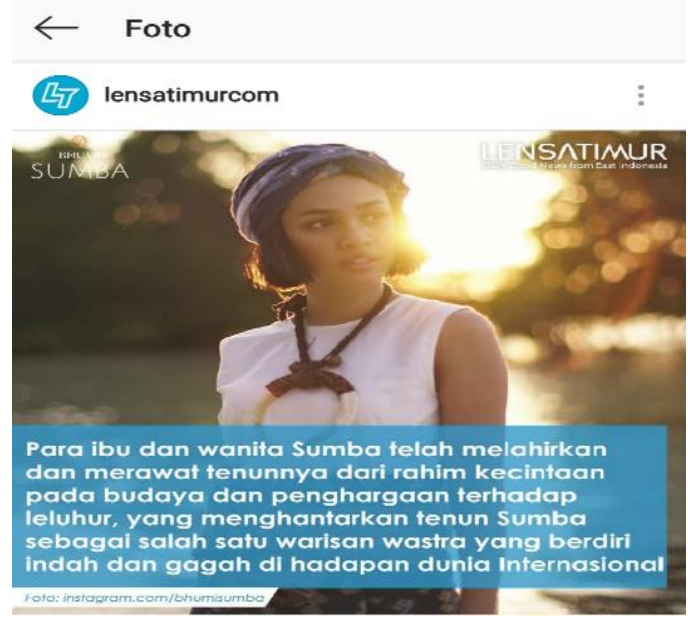

Gambar 7. Contoh Media Partner

(Sumber Media Online Lensatimur) 


\section{Penutup}

Dalam penelitian yang berjudul Strategi Pengelolaan Media Online Lensatimut Dalam Mengangkat Konten Kearifan Lokal, Peneliti dapat menyimpulkan beberapa aspek. Pertama terkait dengan maksud dan tujuan didirakannya Lensatimur sebagai Media yang bertagline Good News. Pada hakekatnya Lensatimur menjadi Media penyeimbang dengan sudut pandang mengangkat kearifan lokal yang ada di wilayah Indonesai Timur. Namun sebagai Media Online baru yang mengakomodir seluruh wilayah Indonesia Timur dari Nusa Tenggara hingga Papua, Lensatimur mengalami hambatan dikarenakan kurangnya jumlah pekerja dan tidak adanya contributor jurnalis tiap daerah dalam memfilterisasi ideasi berita kearifan lokal yang akan diangkat. Aspek kedua terkait dalam operasional, Lensatimur mengalami peningkatan yang pesat dengan jumlah pembaca per artikel per harinya mencapai 500 - 700 pembaca dan pertahunnya mencapai 600 ribu pembaca. Namun kendala yang dihadapi adalah pempublikasian yang tidak mengikuti koridor waktu yang sesusai sehingga publikasi dapat dilakukan kapan saja dan pernah sampai terjadi publikasi dilakukan hanya 1 artikel dalam kurun waktu 3 Bulan.

Aspek ketiga yang didapat selama penelitian adalah Lensatimur sebagai Media yang titik fokusnya di wilayah timur Indonesia, mengambil strategi untuk menjadi Media favorit dengan cara antara lain Sudut Pandang, Konten Artikel, Gaya Bahasa, Segmentasi Khalayak dan Inovasi yang semua itu dilakukan atas dasar kreativitas dan perhitungan yang matang dalam kaitannya dengan operasional Media Online Lensatimur. Aspek keempat atau terakhir ialah Lensatimur membuat semenarik tiap artikel yang dipublish sesuai dengan relevansi anak muda sehingga membangkitkan rasa keingintahuan dalam beberapa poin yaitu mencari artikel yang benar-benar dibutuhkan masyarakat, membuat artikel secara jelas dan runut, berinteraksi dan berkomunikasi melalui snapgram, menciptakan konten ringan untuk dipublish pada sosial media, membuat infografik menarik, dan tentunya menciptakan videografik yang menarik.

Saran yang dapat peneliti sampaikan terdiri atas tiga aspek yang saling berhubungan terkait dengan bagaimana Operasional Lensatimur yang dapat menjadi pembelajaran bagi semua orang. Aspek yang pertama terkait dengan bagaimana saat ini banyak orang yang saling berinovasi dan mendirikan Media Online sendiri sesuai sudut pandang yang berbeda, Aspek yang kedua adalah bagaimana sebagai Insan Komunikasi dapat menjadikan wadah Media Cetak maupun Elektronik sebagai wadah belajar menjadi penulis yang baik dan 
benar, serta aspek yang ketiga terkait dengan hal terbaik menjadi seorang pekerja di Media Online adalah berproses dengan segala konsekuensi yang ada, mulai dari penciptaan konten, riset mendalam, penulisan artikel, dan hingga pada proses pempublishan. Dari pada itu untuk seluruh Pembaca terutama Insan Komunikasi Komunikasi teruslah belajar dan mengasah diri untuk menjadi Jurnalis Media Online yang berintegritas. Terakhir untuk penelitianpenelitian selanjutnya, agar dapat lebih spesifik membandingkan mana media online yang lebih menonjolkan kredibilitas sumber informasi dan mana yang tidak, karena ini berpengaruh kepada pemahaman isis konten para pembaca.

\section{Daftar Pustaka}

Afrizal. 2016. Metode Penelitian Kualitatif. Depok : Penerbit Rajagrafindo Persada.

Ardianti, Elvinaro. et al. 2014. Komunikasi Massa. Bandung : Penerbit Simbiosa Rekatama Media.

Littlejhon, Stephen W (Mohammad Yusuf Penerjemah). 2009. Teori Komunikasi : Theories of Human Communication. Jakarta : Penerbit Salemba Humanika.

Nasrullah, Rulli. 2016. Teori Dan Riset Media Siber Cybermedia. Rawamangun : Penerbit Prenadamedia Group.

Rivers, William L (Haris Munandar, Dudi Priatna Penerjemah). 2005. Mass Media And Modern Society. Rawamangun : Penerbit Prenadamedia Group.

Rahmitasari, Diyah Hayu. 2017. Manajemen Media Di Indonesia. Jakarta : Penerbit Pustaka Obor Indonesia.

Romli, Khomsahrial. 2016. Komunikasi Massa. Jakarta : Penerbit Grasindo.

Sirait, Hasudungan. et al. 2007. Meretas Jurnalisme Damai Di Aceh. Jakarta : Penerbit Yayasan Obor Indonesia.

Trianton, Teguh. 2016. Jurnalistik Komprehensif. Yogyakarta : Penerbit Ombak.

Tebba, Sudirman. 2008. Etika Media Massa Indonesia. Tangerang : Penerbit Pustaka Irvan. 